\title{
Feels like home: Effect of transnational identities on attitudes towards foreign countries
}

Journal of Peace Research

$1-15$

(C) The Author(s) 2020

Article reuse guidelines:

sagepub.com/journals-permissions DOI: $10.1177 / 0022343320943251$ journals.sagepub.com/home/jpr

๑SAGE

\author{
Efe Tokdemir (1)
}

Department of International Relations, Bilkent University

\begin{abstract}
How do people react to foreign actors' involvement in a conflict in a third party? Many studies have explored how individuals react to their country's foreign policy choices, as well as how they react to the policies targeting their countries. Yet, we know less about how they form their attitudes regarding the policies not directly aiming at their own countries, and hence, their well-being. Building on intergroup relations and employing a social psychological approach, this article argues that identity serves as a heuristic through which individuals evaluate foreign actors, and their policies targeting in- and out-group members living abroad. Conducting a survey experiment in Turkey, I test my claims in the context of the Syrian Civil War. The findings of the experiments reveal that transnational identity ties have an impact on attitude formation: Turks and Kurds express positive/negative attitudes towards the USA and Russia conditional on whether their involvement to the conflict favor/disfavor their in-group/out-group across the border. Broadly speaking, the results show that domestic cleavages are of importance in predicting the public's reaction to the developments in international politics, which implies a necessity of taking domestic politics in designing soft power promotion and public diplomacy strategies for many global and regional powers in attempting to win hearts and minds abroad.
\end{abstract}

\section{Keywords}

foreign policy, foreign public opinion, intergroup conflict, transnational identity

\section{Introduction}

Many states, especially major powers like the USA and Russia, have foreign policy interests that span the globe, and some of their policy measures elicit significant amounts of support or discontent among foreign publics abroad. Millions of Europeans taking to the streets and protesting US military intervention in Iraq in 2003, or hundreds of thousands of Middle Easterners angrily gathering around embassies and burning US flags whenever the tension increases around the Israeli-Palestinian conflict clearly evidence individuals' responsiveness to the developments not only concerning their own country, but third parties, as well.

The literature on foreign policy attitudes has identified multiple factors such as ideology (Herrmann, Tetlock \& Visser, 1999; Holsti, 2004), elite and media cues (Gelpi, 2010; Gaines et al., 2007), personality traits and values (Bayram, 2016; Kam \& Kinder, 2007; Kertzer et al., 2014), social networks (Radziszewski, 2013), attachment to national identity (Becker, 2009; Telhami \& Barnett, 2002), and strategic factors (Jentleson, 1992; Gelpi, Feaver \& Reifler, 2006) playing role in shaping an individual's attitudes toward foreign policy choices. These studies, however, focus primarily on what causes individuals to develop preferences in regard to the foreign policy choices of their own countries.

It is merely the studies on anti-Americanism that have offered insights into the possible explanations for the foreign publics' responses to the USA and its policies. That said, it is either what a country is/represents (e.g. US culture and values) or what it does (i.e. US policies)

Corresponding author: efe.tokdemir@bilkent.edu.tr 
that are to blame for the hostile attitudes of publics abroad (Nye, 2004; Lynch, 2007). Nonetheless, the findings are not always supportive of these accounts. This is because further investigation shows that many people have quite positive feelings about US popular culture, science, and business (Chiozza, 2010). Moreover, the efforts on the part of US policymakers to 'win hearts and minds' by offering the 'right' policies in the Middle East have proven to be largely futile (Bush \& Jamal, 2014; Corstange \& Marinov, 2012). Likewise, there are also within-country variations in regard to attitudes towards the USA, and we should strive to more fully understand publics abroad.

The existing literature is insufficient in answering questions concerning when, how, and why major power foreign policies are likely to produce different kinds of reactions among foreign publics. However, countries like the USA, Russia, and China heavily invest in public diplomacy efforts to promote their soft power abroad, since not having the support of foreign publics can result in damaging the effectiveness of policies implemented on a global scale. Hence, we should give a more comprehensive look at the externalities of foreign policies and try to learn more about how publics abroad view those policies in response. In light of this research gap, this article aims to explore social-psychological factors of attitude formation processes of individuals in response to the policies foreign actors implement towards the third parties. It attempts to discover what shapes people's reactions about the foreign actors' involvement concerning the third parties, and why.

I suggest that evaluation of individuals' transnational identity ties is necessary in examining the source of their attitudes. This is mainly because they serve as mental shortcuts that shape perceptions about other states and their policies regarding third parties. By building on the premises of social identity theory, I argue that the political identities of individuals influence how they perceive and react to a given state's involvement at home and abroad. An in-group-out-group dichotomy can also extend across borders when individuals on either side of a given border share common transnational ethnic, religious, or sectarian identities with others. This, in return, pushes individuals to seek for consistency in their attitude formation, as the borders of 'home' and 'abroad' are blended in their cognitive map because any development concerning the members of an in-group and/or out-group has an impact on the status quo of domestic power balance between the groups. On this basis, I propose that individuals are motivated to consider the impact of a foreign state's policies targeting other countries, where their 'brethren' live.

To test this transnational process of attitude formation towards foreign actors, this article explores the attitudes of Turkish and Kurdish citizens of Turkey towards US and Russian involvements in the Syrian Civil War (SCW), and their influence on ethno-religious groups, that is, Kurdish rebels, in Syria. Conducting a survey experiment with 1,136 individuals in Turkey, where an identity cleavage between Turks and Kurds provides an appropriate context for manipulating the target and the goal of these policies in order to analyze the differing attitudinal responses of individuals, I investigate how transnational ethnic ties condition people's attitudes in their assessment of the USA and Russia as a result of their policies in the SCW. I demonstrate how intergroup conflict conditions the attitudes of individuals towards foreign states by triggering 'the friend of my friend is my friend' and 'the friend of my enemy is my enemy' rationales.

This study mainly locates into the behavioral IR literature by examining how a foreign public perceives and responds to policy choices of states and makes generalizable contributions both to the existing scholarship and to policymaking in three main ways. First, by probing the impact of transnational ties and domestic predispositions among identity-based groups, I investigate the externalities of foreign policies at the public level. Second, I offer a comprehensive account of the socialpsychological sources that determine how individuals react to other countries based on their foreign policies. Third, the contributions of this article go beyond the anti-Americanism literature such that it will have an impact on the literature on comparative foreign policy based on its examination of the micro-level impact of both US and Russian foreign policy. In addition to its primary contributions, this study also adds to the conflict literature by examining individuals' hostile attitudes towards foreign actors, which base a recruiting pool for violent non-state actors resorting to violence. Moreover, the lessons derived from this research provide us with valuable insights about effectiveness of policies, which may ideally serve for soft power building strategy, as most of them heavily consider winning, or at least not losing, hearts and minds abroad when crafting public diplomacy strategies.

In the remainder of the article, first, I develop a theoretical framework that builds on social identity theory to explain the creation of an 'us vs. them' process in individual attitude formation. Then, I demonstrate how the notion of 'others' concerns' becomes part of a 
'domestic issue' through transnational identity ties, and theorize how people react, in turn. Third, I explain the experimental design in the survey conducted in Turkey. Lastly, I present the results and conclude with a discussion of my findings and their implications.

\section{The role of social identity in shaping politics attitudes}

People are cognitive misers, and this applies to their reliance on mental shortcuts, that is, heuristics, and biased information processing (Popkin, 1991; Lau \& Redlawsk, 2001). Given the difficulty and lack of expertise in accessing information pertaining to international events for ordinary citizens, this statement becomes even more relevant when applied to the formation of attitudes towards foreign actors and their policies. In fact, it is for this reason that referring to the policy preferences of foreign states in order to understand how they are viewed abroad is problematic. It is not the actual policies, but the perceptions of these policies, which are often biased and distorted by the elite and media conditioning people's attitudes towards the source of these policies (Gelpi, 2010; Gaines et al., 2007). Indeed, Blaydes \& Linzer (2012) also demonstrate the role of an elite component in anti-American attitudes among Middle Easterners, which is fed by a secularist-Islamist cleavage. Hence, the lenses through which people see the world indicate how they will assess foreign states and their policy choices.

Social identity is one of the foremost tools in providing people with lenses through which they perceive and interpret politics and in giving rise to motivating biases (Tajfel, 1982; Herrmann, 2017; Hurwitz \& Peffley, 1987). Defined as a 'common form of a group identity that involves the incorporation of group membership into the concept of self (Huddy, 2013), social identity bridges the concept of self to a group to which the individual belongs (Tajfel, 1981). Most social identities are politically relevant, and salient, especially when they are based on racial, religious or ethnic ties, which further increases their salience (Turner et al., 1987; Oakes, 2002). As a result, identity becomes an indicator of the political predisposition of the group's members and regulates their relations with other groups and the state. This is because social identity transforms the concept of self and redefines it as a part of the group (Tajfel, 1982).

In this regard, self-interest is also redefined such that individuals with a salient group identity may prioritize group interest over self-interest. As a result, group members are largely motivated to defend the group's interest and integrity (Brewer, 2011). Social identity theory contends that threats to the group identity bind in-group members together in the pursuit of common interests. Specifically, competition over tangible interests, along with threats to the group identity, plays a major role in interpreting the surroundings, and hence, shaping attitudes towards others (Sherif, 1967). In line with these, there is ample evidence in the literature on civil war that ethnic kin fuel civil wars in neighboring countries, and indeed, fears of extinction as well as well-being of the group serve as motivations to keep loyal and allied with broad group interests (Cederman et al., 2013; Saideman, 2001).

A salient and politically relevant identity does not only serve as a heuristic to form an opinion about the policies. It also influences the information processing of individuals by biasing their reasoning. The literature on motivated reasoning contends that individuals process information with the motivation of affirming the goals set by their social identities (Kunda, 1990; Lodge \& Taber, 2000; Spears, 2011). With this motivation, they can derive psychological benefits for individuals such as boosting self-esteem by positively discriminating the group they are part of against the others, as well as material benefits by showing they are loyal members of the group (Fiske, Cuddy \& Glick, 2007; Kahan, 2016).

Furthermore, the political identity of an individual largely determines the extent to which they can access limited resources. Many individuals are deprived of social and/or political rights solely because they belong to a minority group based on race, ethnicity, religion, and/or language. Those deprived of the resources are more likely to blame the identity ties for the denial of resources (Horowitz, 1985; Miller, Bolce \& Halligan, 1977), which only further increases the saliency of identity and reinforces intergroup dichotomy (Pratto et al., 1994, 2014). A realist approach to intergroup conflict suggests that competition for resources results in in-group favoritism bias, which makes group members favor each other, as access to given resources requires a collective effort (Tajfel, 1981; Tajfel \& Turner, 1979). Plus, a political context built on ethnoreligious conflict may also lead to out-group negativity because of an increased threat perception, a salient group identity, rigid group borders, and ethnocentrism (Coser, 1956; Hewstone, Rubin \& Willis, 2002; LeVine \& Campbell, 1972).

There is no reason to hold that either in-group favoritism or out-group negativity operates solely within national borders, though many studies take national borders as a scope condition in probing the impact of policy 
choices on public opinion. After all, the very definition of identity incorporates group ties, which can cross the border through ethnicity and religion, into the concept of self. In fact, civil war literature also shows that actors and events are not constrained by national borders and display transnational character in diffusion of ideas and resources, and identity is the foremost indicator of this diffusion (Buhaug \& Gleditsch, 2008; Cederman et al., 2013; Lake \& Rothchild, 1998; Weidmann, 2015). One example of this diffusion is the case of jihadists coming from all over the world to join the ranks of their 'Muslim brothers' in their holy war against 'the infidels'. Hence, the involvement of a foreign actor into a third country may easily generate a spillover effect through transnational identity ties and domestic intergroup tensions. What is the mechanism, then, through which people, who share transnational identity abroad, form attitudes towards foreign actors concerning their involvement in third parties?

Consistency theories in psychology suggest that individuals account for the source of ideas and policies in forming their attitudes. Should an offer come from an out-group, adversary, or an antagonist, then the value of the proposal decreases in the eyes of the recipients (Ross \& Stilinger, 1991; Ross \& Ward, 1995). One of the underlying reasons for this cognitive bias is skepticism. Human beings are more inclined to look for ambiguities and inconsistencies when an out-group, that is untrusted and antagonistic, makes a proposal (Ross \& Stilinger, 1988; Ross, 1995). Reactive devaluation theory contends that every individual interprets gains and losses using heuristics differently. Hence, regardless of what a proposal actually offers to all parties, each individual will rely on their biased divergent construal in assessing the pros and cons of the proposal depending on how they perceive the 'source' (Tversky \& Kahneman, 1974; Ross $\&$ Ward, 1995). Likewise, social balance theory proposes that a policy or proposal can be evaluated based on its linkages with the source (Heider, 1958; Greenwald et al., 2002). Hence, individuals seek consistency in their attitudes in a network of relations and feel pressure to correct any imbalance of sentiments and affinity by shifting their opinion until cognitive consistency is achieved (Hummon \& Doreian, 2003).

Drawing on social identity theory for attitude formation, and cognitive consistency theories for extending attitude formation across borders, I propose that individuals update their attitudes towards a foreign state by accounting for how their involvement serves the interests of the in- and out-group abroad in the third party. Given that in-group vs. out-group dichotomy formed around a salient identity is not limited within the national borders, any development concerning their material or moral interests abroad also influences the status quo in domestic power balance at home, and hence, provides a rationale for ensuring consistency in attitudinal response to third-party policies. In the following section I will continue explaining the rationale for selecting the case of the Syrian Civil War and conditional attitude formation of Turks and Kurds in Turkey regarding the US and Russian involvement in Syria.

\section{Case selection and hypotheses}

To empirically test the role of identity and the propositions of cognitive consistency theories in the formation of attitudes towards third parties, I take the Syrian Civil War (SCW) as the focus of this study. Using a survey experiment I conducted in Turkey, I investigate whether identity and transnational ties impact individuals' attitudes towards the USA and Russia regarding their policies in Syria. I focus on probing the differential effect among Turks and Kurds in response to policies favoring/ disfavoring their in-group/out-group abroad. The SCW case and the Turkish context provide us with three cleavages in solving the puzzle: (1) the presence of a salient ethnonational cleavage and intergroup threat perceptions between Turks and Kurds in Turkey, (2) the presence of transnational ties for both ethnic groups in Syria, and (3) active and direct involvement of major international actors - the USA and Russia - which has impact on the future of both identity groups.

To begin with, Turkey is a country with a long history of ethnically motivated conflict initiated by the Kurdistan Workers' Party (PKK) - a rebel group that resorted to terrorism to establish an independent Marxist-Leninist Kurdish state, which has contributed to out-group negativity over time. With the support of Syrian, Iraqi, and Iranian Kurds, the PKK caused more than 40,000 casualties in attacks on civilians and military targets. Despite the transformation of PKK objectives in years (i.e. from demanding independence to local autonomy) and the reform process initiated by the Turkish government in the 2010s, the conflict between the PKK and Turkey reignited in June 2015 causing the deaths of more than 400 civilians and 800 security officers. ${ }^{1}$ Along with a history of conflict, a major salient political cleavage based on the respective ethnic identities of Turkish and Kurdish communities also exists (Sarigil \& Karakoc, 2017).

\footnotetext{
${ }^{1}$ Please see for details: https://140journos.com/sayilarla-1984ten-buyana-pkk-ile-catismalardaki-olumler-5ce123d214be.
} 


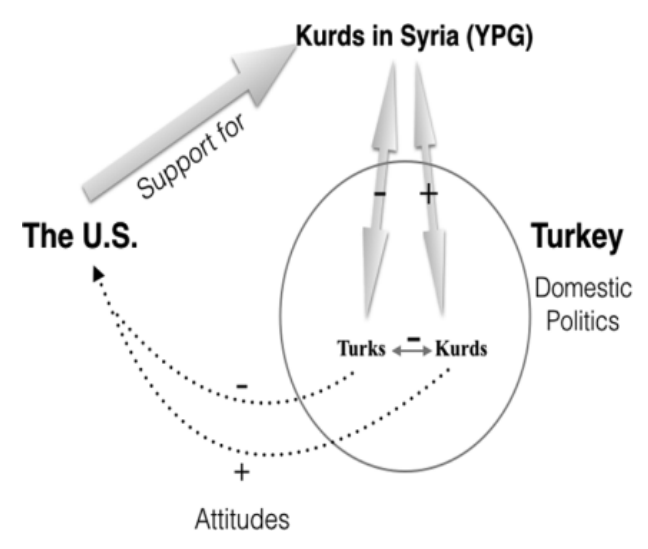

Figure 1. Theoretical framework and hypotheses

Nevertheless, despite the issuance of electoral bans on Kurdish parties, $10 \%$ electoral threshold, and the arrests of major political figures, Kurdish politicians and the Kurdish political party - the People's Democratic Party (HDP) - won the majority of the votes with large margins in Kurdish-majority cities in recent elections.

Secondly, many Kurds and Turkmens living in Syria constitute an appropriate population for exploring the role of transnational identity. Kurds and Turkmens living in Syria located along Turkey's borders have always engaged in formal and informal economic activities with their brethren living on the Turkish side of the border. ${ }^{2}$ Existing political and social connections with the Kurds and Turks in Turkey and Syria deepened further with the start of the war in Syria. Not only did many refugees cross the border, but also many Kurds left Turkey to join the ranks of the YPG, Kurdish rebels fighting against ISIS, in defense of Kobane, a Kurdish city located on the border. Prominent Kurdish figures have supported the resistance against ISIS in Kobane, called for the Turkish government to militarily intervene in support of the YPG, and celebrated the eventual success. ${ }^{3}$ However, Turks strongly diverge from Kurds in their attitudes toward the YPG. Likewise, the Turkish government has referred to the YPG many times as the offspring of the PKK. ${ }^{4}$

Lastly, the SCW provides a setting that is appropriate for testing how Turks and Kurds living in Turkey interpret foreign states' policies with impacts on the lives of

\footnotetext{
${ }^{2}$ Please see for details: http://www.aljazeera.com.tr/blog/bin-kisi-deolse-kacakcilik-bitmez.

${ }^{3}$ Please see for details: https://tr.euronews.com/2020/09/25/kobaniolaylarinda-ne-oldu-eylemler-nasil-sonlandi.

${ }^{4}$ Please see for details: https://www.hurriyetdailynews.com/ president-erdogan-says-pyd-no-different-than-pkk-for-turkey-73 172.
}

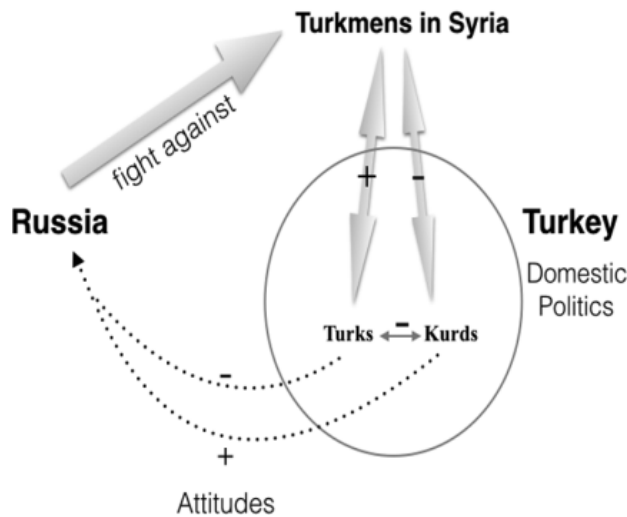

their brethren and enemy. It is an ongoing war as well as a salient issue at both the national and international levels. Accordingly, many scholars and practitioners argued that the result of SCW would have direct consequences for domestic power balance between Kurds and Turks in Turkey, since possible gains of Kurdish fighters in Syria could constitute a strong step towards an independent Kurdish state including southeastern districts of Turkey (Cizre, 2001; Kirisci \& Winrow, 1997). This is clearly evidence showing Turks see not only Kurds in Turkey but also Syrian Kurds as out-groups in regard to assumed and existing identity ties among Kurds in the region. Moreover, international actors are also heavily involved in the conflict, and both the USA and Russia are among the actors fighting against ISIS by providing financial and military support to various ethno-religious groups including Kurdish fighters and Turkey-backed armed groups. Even though the source and content of these external actors' actions are always open to speculation and manipulation, their involvement strikes the right note in evaluating the impact of third-party policies that could influence domestic power balance at home (Tokdemir et al., 2020).

Overall, applying the theoretical mechanism outlined in the previous section to the complex equation of Turks vs. Kurds in Turkey and Syria, and US and Russian involvement in the SCW, I expect to find that individuals cognitively balance their attitudes toward the USA and Russia. As described in Figure 1, a triadic relationship between the Turks, the Kurds, and the USA or Russia, therefore, should be in perfect logical harmony. Accordingly, Kurds will form their attitudes by developing a positive attitude towards the USA as a result of US policies supporting Kurds in Syria, whereas Turks will develop a negative attitude towards the USA, as the same policy is in favor of their out-group, whom they perceive 
to be a threat. And, this will also be true in regard to people's attitudes toward Russia, considering Russian policies defending the Assad regime against the Turkmens, the in-group of the Turks in Turkey:

H1: In-group favoritism extending beyond the borders:

(a) Turks who are exposed to the treatment suggesting the Russian bombing of Turkmens will express a more negative attitude towards Russia than Turks who are not.

(b) Kurds who are exposed to the treatment suggesting the US support for the YPG will express a more positive attitude towards the USA than Kurds who are not.

H2: Out-group negativity extending beyond the borders:

(a) Turks who are exposed to the treatment suggesting the US support for the YPG will express a more negative attitude towards the USA than Turks who are not.

(b) Kurds who are exposed to the treatment suggesting the Russian bombing of Turkmens will express a more positive attitude towards Russia than Kurds who are not.

\section{Research design}

To test my hypotheses, I embedded an experiment into a face-to-face public opinion survey conducted in Turkey between 24 December 2016 and 22 January 2017 - a time frame in which the conflict was still ongoing with the participation of all actors in Syria. A national survey company, Infakto, conducted the interviews in 141 randomly chosen districts from all three cities. From each district, four streets were randomly picked from the official records of the street lists. Then, from each randomly chosen street, two houses were selected randomly for an interview. In the case of no response from the household, the surveyors skipped three houses and interviewed a household member at the fourth one. Thirty-one enumerators, who were carefully selected by Infakto to represent the ethnic and religious characteristics of given cities and districts, conducted the interviews. The average time to complete the survey was 19 minutes. Pre-estimation analysis of variance across control and treatment groups reveals that randomization is successful (see Online appendix A). The experiments were fielded in three major cities, namely Istanbul $(\mathrm{N}=518)$, Gaziantep $(\mathrm{N}=315)$, and Diyarbakir $(\mathrm{N}=303)$ on a randomly drawn sample of 1,136 people over the age of 18 . Acknowledging the fact that our sampling decisions prevent us from having a nationally representative sample, and hence generalizing the findings across Turkey, these cities are chosen to ensure sufficient participation from both Turks and Kurds. Moreover, the sample reflects socio-economic and confessional demographics within these cities. Indeed, while Istanbul is a cosmopolitan city with nearly 15 million inhabitants including various ethnic and religious backgrounds, Diyarbakir is a Kurdish majority city with a population around one million. Gaziantep, in contrast, is a heavily Turkish dominated city located along the Syrian border. That said, my operationalization decision prioritizes zooming into the identity cleavages heavily affected by the consequences of the SCW at the expense of sacrificing from a nationally representative sample.

For the experimental components, I designed short vignettes informing respondents about US and Russian foreign policy choices targeting non-state armed actors fighting in Syria. In these experiments, I asked Turks and Kurds living in Turkey about their attitudes towards the USA and Russia after they had read the assigned vignette. By informing the respondents about the policy choices targeting their 'brethren' and/or their 'enemies' abroad, I measured differing attitudes towards the USA and Russia regarding their policies favoring/opposing the interests of the in-group/out-group abroad. Experimental vignettes are short and simple to effectively present the engagement of the USA and Russia into the SCW in favor of or opposed to the main identity groups in Northern Syria, that is, Kurds and Turkmens who are members of either an in-group or an out-group of Turks and Kurds in Turkey. In order to avoid possible problems in conducting research on a sensitive topic, I avoid using any deception. Therefore, I conducted two experiments instead of a more conventional factorial design. Despite its limitations, such as not using provocative fake news to effectively endorse the policy choices and inability of clearcut comparison among policies and countries, this is a safer approach for the security of enumerators as well as for the comfort of survey respondents. Moreover, I believe this design choice does not have a substantive impact on the theory testing, as my goal is not to make comparisons among policies and countries, but to see the impact of identity heuristics in influencing individuals' attitudes towards third parties.

\section{Experiments}

The purpose of the first experiment was to see the diverging attitudes of Kurds and Turks toward the USA in regard to the US engagement with Kurdish insurgents, who are an in-group of the Kurds and an out-group of 
the Turks. In the control group, I measured individuals' attitudes towards the USA by using a scale ranging from 0 to 10 , the highest scores indicating the most positive attitude. In the treatment groups, the survey respondents received a brief about US policies in Syria before reporting their attitudes. In the ethnic treatment group, the respondents were informed about US policies in regard to the YPG Kurdish insurgent group. In this brief, the respondents were told that (1) the YPG was a Kurdish insurgent organization, (2) the USA was supporting the group militarily and economically, and (3) both international and national sources had confirmed this support. To control for the impact of a crosscutting identity cleavage - sectarian identity: Sunni vs. Alevi - I also introduced a sectarian treatment, ${ }^{5}$ which informs participants about US policies in regard to the Sunni insurgent group, the Free Syrian Army, similar to the ethnic treatment. In order to strengthen the effect of the manipulation, I also detail the proofs of support, such as the use of US weaponry and Kurdish insurgents wearing US uniforms with a US flag on them.

The second experiment focuses on the attitudes of Turks and Kurds toward Russia in regard to Russian engagement with Turkmens, who are an in-group of the Turks. I have two principal reasons for looking at Russian policies targeting Turkmens: first, I do not use any deception in the vignettes, and the USA does not have a clear policy choice targeting Turkmens. Instead, the Turkish media have constantly reported violent Russian engagement with the Turkmens, who are fighting against the Assad regime. Second, by testing the impact of group identity on attitudes toward Russia, I also have an opportunity to control the robustness of my theoretical claims. In so doing, I do not limit the findings of this study to the USA. In the control group, I measured individuals' attitudes towards Russia, again by using a scale ranging from 0 to 10 . In the ethnic treatment group, before I measured the attitudes of individuals, the respondents received a brief about Russian policies in Syria in regard to the Turkmens. In this brief, the respondents were told that (1) the Turkmens were fighting in the SCW, (2) Russia was supporting the Assad regime militarily and economically, and (3) both international and national sources had shown proof that Russia had bombed the Turkmens. In the sectarian

\footnotetext{
${ }^{5}$ Although the majority of Kurds and Turks are Sunni, there are many Alevi citizens from both groups. Yet, lack of a salient political identity and discretion of Alevi citizens in surveys prevents us from deeply investigating the role of sectarian cleavage along with the ethnic one.
}

treatment for the second experiment, the respondents were briefed about Russian policies pertaining to Sunni Muslims living in Syria (see Figure 2 for the vignettes).

\section{Independent variables: Ethnicity and demographics}

In addition to responding to the questions designed to measure attitudes towards the USA and Russia, the survey respondents answered a set of demographic questions. These questions were crucial in determining the heterogeneous effects of the treatments on distinct identity groups, as hypothesized. To this end, we asked the survey respondents how they identify themselves ethnically. Although self-reporting ethnic identity may be problematic, my sampling decision allows me to overcome the underrepresentation problem and to ensure a representative sample of the cities. As explained earlier, my main reason for conducting the survey in three cities, one of them having a Kurdish majority most of whom voted for the Kurdish party, was to minimize the problem of underrepresentation and possible bias in the sample.

Further, I controlled for the survey respondents' Age (continuous), Gender (binary), Educational status (ordinal), Income level (ordinal), Urbanity (binary), and Religiosity (continuous), an index variable consisting of the individual's support for Sharia law, frequency of religious practices, and self-reported importance of religion in their lives. Lastly, to account for the role of elite rhetoric and political preferences, I added Incumbent party support, a variable coded 1 if the respondent says she "would vote for [the incumbent party] if there were general elections to be held on this Sunday', and coded 0 otherwise. Although randomization in the experimental setting had already stripped away the effect of confounding factors by keeping all the other factors constant, controlling for these demographic variables is informative for seeing the heterogeneous effects, such that it was possible to identify which people expressed a stronger anti- or pro-US or a stronger anti- or pro-Russian attitude. The descriptive statistics are reported in Online appendix B.

\section{Results}

According to my hypotheses, the ethnic orientations of individuals, which determine their in-group and outgroup, condition how they perceive the policies of the USA and Russia in Syria, and develop attitudes towards them, accordingly. Therefore, instead of simply looking at the average treatment effects, I present the results pertaining to the heterogeneous treatment effects as the former cancels out the conditional effect. Nevertheless, I 


\begin{abstract}
US - Control Group - I'd like to get your feelings about the Unites States using a ten-scale rating. [Rating explanation] How would you rate the US?

US - Ethnic Treatment Group - A civil war is ongoing within Syria with the participation of many armed groups. One of these groups is PYD/YPG, which is founded by Kurds. The US provides Kurdish insurgent group PYD/YPG with military and economic support. International and national news agencies display the extent of the support, by reporting pictures of Kurdish insurgents using American weaponry, and wearing uniforms carrying the American flag on it. Now, I'd like to get your feelings toward the United States. [Rating explanation] How would you rate the US?

US - Sectarian Treatment Group - A civil war is ongoing within Syria with the participation of many armed groups. One of these groups is Free Syrian Army, which is founded by moderate Sunni Muslims. The US provides moderate Sunni insurgent group Free Syrian Army with military and economic support. International and national news agencies display the extent of the support, by reporting pictures of moderate Sunni insurgents using American weaponry and wearing uniforms carrying American flag on it. Now, I'd like to get your feelings toward the United States. [Rating explanation] How would you rate the US?

Russia - Control group - I'd like to get your feelings toward Russia using a ten-scale rating. [Rating explanation] How would you rate Russia?

Russia - Ethnic Treatment group - A civil war is ongoing within Syria with the participation of many armed groups. One of these groups is Assad regime. Russia provides Assad regime with military and economic support. International and national news agencies display the extent of the support, by reporting pictures of Russian fighters bombing and destroying Turkmen towns. I'd like to get your feelings toward Russia. [Rating explanation] How would you rate Russia?

Russia - Sectarian Treatment group - A civil war is ongoing within Syria with the participation of many armed groups. One of these groups is Assad regime. Russia provides Assad regime with military and economic support. International and national news agencies display the extent of the support, by reporting pictures of Russian fighters bombing and destroying Sunni towns. I'd like to get your feelings toward Russia. [Rating explanation]. How would you rate Russia?
\end{abstract}

Figure 2. Vignettes

report the average treatment effects for both experiments in Online appendix C.

Although the dependent variables are measured in 11point Likert scales ranging from 0 to 10 , preliminary analysis reveals that the parallel regression lines assumption is violated; therefore, estimating an ordered logistic/ probit regression is not an option to predict individuals' attitudes. Moreover, the interpretation of the interaction terms as the key explanatory variables revealing the heterogeneous impact of the treatments is straightforward in ordinary least squares regression. That said, I report the main finding of the heterogeneous treatment effects from OLS regression with robust standard errors.

The findings of the first experiment, that is, the US experiment, are reported in Table I. In order to see the impact of ethnic identity, which primes the most salient identity in Turkey, I report the results of ethnic treatment vs. control group and sectarian treatment. ${ }^{6}$ The findings provide support for out-group negativity of Turks towards Kurds in Syria (H2a), as the interaction term is both significant and in the expected direction. Accordingly, respondents who self-reported as ethnic Turks express a

\footnotetext{
${ }^{6}$ In the robustness check, I also reported the results of ethnic treatment vs. control group (Online appendix E) as well as sectarian treatment vs. control group (Online appendix F), alone.
}

significantly negative attitude towards the USA when informed about US policies favoring the Kurdish rebels YPG in Syria. Compared to the Turks who were not exposed to the YPG treatment, the Turks who were exposed to this treatment score the USA more than a half point lower on average. As shown in Model 2, the average score given to the USA by Turks in my sample that were not exposed to the ethnic treatment was 1.94, whereas the average score given to the USA by Turks who were exposed to the treatment was 1.42 (see Figure 3).

On the other hand, the findings show that Kurds are slightly in favor of US policies in Syria providing more support to their brethren across the border. However, this result is not statistically significant. Substantive findings show that when informed about US policies in Syria, those who self-report as Kurds express a more positive attitude towards the USA than do Turks who have been informed likewise. Accordingly, as shown in Model 4, whereas an average score given to the USA by Kurds who were not exposed to the ethnic treatment is 2.74, it is 3.03 among Kurds who were exposed to the treatment. Nonetheless, overlapping confidence intervals prevent us from confirming in-group favoritism among Kurds extended beyond the borders ( $\mathrm{H} 1 \mathrm{~b})$.

In the second experiment, I briefed randomly assigned respondents about Russian policies in Syria. I 
Table I. Heterogenous treatment effects for Experiments 1 and 2

\begin{tabular}{|c|c|c|c|c|c|c|c|c|}
\hline DV: Attitudes towards & $\begin{array}{l}(1) \\
U S\end{array}$ & $\begin{array}{l}(2) \\
U S\end{array}$ & $\begin{array}{l}(3) \\
U S\end{array}$ & $\begin{array}{l}(4) \\
U S\end{array}$ & $\begin{array}{c}\text { (5) } \\
\text { Russia }\end{array}$ & $\begin{array}{c}\text { (6) } \\
\text { Russia }\end{array}$ & $\begin{array}{c}\text { (7) } \\
\text { Russia }\end{array}$ & $\begin{array}{c}\text { (8) } \\
\text { Russia }\end{array}$ \\
\hline Turk (YPG Treatment=l) & $\begin{array}{c}-0.612^{\dagger} \\
(0.333)\end{array}$ & $\begin{array}{r}-0.807^{*} \\
(0.385)\end{array}$ & & & & & & \\
\hline Kurd (YPG Treatment=l) & & & $\begin{array}{l}0.604^{\dagger} \\
(0.347)\end{array}$ & $\begin{array}{c}0.780^{\dagger} \\
(0.400)\end{array}$ & & & & \\
\hline Turk (Turkmen Treatment $=1$ ) & & & & & $\begin{array}{r}-0.588 \\
(0.365)\end{array}$ & $\begin{array}{r}-0.729^{\dagger} \\
(0.409)\end{array}$ & & \\
\hline Kurd (Turkmen Treatment $=\mathrm{l}$ ) & & & & & & & $\begin{array}{l}0.558 \\
(0.366)\end{array}$ & $\begin{array}{l}0.644 \\
(0.412)\end{array}$ \\
\hline YPG Treatment & $\begin{array}{l}0.198 \\
(0.299)\end{array}$ & $\begin{array}{l}0.292 \\
(0.344)\end{array}$ & $\begin{array}{r}-0.407^{* *} \\
(0.145)\end{array}$ & $\begin{array}{r}-0.489^{* *} \\
(0.169)\end{array}$ & & & & \\
\hline Turkmen Treatment & & & & & $\begin{array}{r}-0.186 \\
\quad(0.296)\end{array}$ & $\begin{array}{l}0.106 \\
(0.330)\end{array}$ & $\begin{array}{r}-0.740^{* *} \\
(0.216)\end{array}$ & $\begin{array}{r}-0.576^{* *} \\
(0.238)\end{array}$ \\
\hline Turk & $\begin{array}{r}-0.883^{* *} \\
(0.180)\end{array}$ & $\begin{array}{r}-0.709^{* *} \\
(0.206)\end{array}$ & & & $\begin{array}{l}0.172 \\
(0.206)\end{array}$ & $\begin{array}{l}0.071 \\
(0.245)\end{array}$ & & \\
\hline Kurd & & & $\begin{array}{r}0.963^{* *} \\
(0.187)\end{array}$ & $\begin{array}{r}0.772^{* *} \\
(0.213)\end{array}$ & & & $\begin{array}{r}-0.358^{\dagger} \\
(0.208)\end{array}$ & $\begin{array}{r}-0.191 \\
\quad(0.252)\end{array}$ \\
\hline Age & & $\begin{array}{l}-0.013^{*} \\
\quad(0.006)\end{array}$ & & $\begin{array}{l}-0.013^{*} \\
\quad(0.006)\end{array}$ & & $\begin{array}{l}0.008 \\
(0.008)\end{array}$ & & $\begin{array}{l}0.007 \\
(0.008)\end{array}$ \\
\hline Male & & $\begin{array}{c}0.275^{\dagger} \\
(0.160)\end{array}$ & & $\begin{array}{c}0.282^{\dagger} \\
(0.160)\end{array}$ & & $\begin{array}{r}0.528^{* *} \\
(0.187)\end{array}$ & & $\begin{array}{r}0.533^{* *} \\
(0.186)\end{array}$ \\
\hline Education & & $\begin{array}{l}0.096 \\
(0.063)\end{array}$ & & $\begin{array}{l}0.095 \\
(0.063)\end{array}$ & & $\begin{array}{l}0.111 \\
(0.074)\end{array}$ & & $\begin{array}{l}0.108 \\
(0.074)\end{array}$ \\
\hline Income & & $\begin{array}{r}-0.105^{* *} \\
(0.039)\end{array}$ & & $\begin{array}{r}-0.102^{* *} \\
(0.039)\end{array}$ & & $\begin{array}{c}0.091^{*} \\
(0.045)\end{array}$ & & $\begin{array}{c}0.081^{\dagger} \\
(0.045)\end{array}$ \\
\hline Urban & & $\begin{array}{l}0.076 \\
(0.286)\end{array}$ & & $\begin{array}{l}0.105 \\
(0.288)\end{array}$ & & $\begin{array}{r}0.800^{* *} \\
(0.284)\end{array}$ & & $\begin{array}{c}0.788^{* *} \\
(0.286)\end{array}$ \\
\hline Religiosity & & $\begin{array}{r}-0.181^{\dagger} \\
(0.095)\end{array}$ & & $\begin{array}{r}-0.182^{\dagger} \\
(0.094)\end{array}$ & & $\begin{array}{l}-0.091 \\
\quad(0.102)\end{array}$ & & $\begin{array}{l}-0.090 \\
\quad(0.102)\end{array}$ \\
\hline Incumbent Party Support & & $\begin{array}{r}-0.087 \\
(0.164)\end{array}$ & & $\begin{array}{r}-0.067 \\
(0.165)\end{array}$ & & $\begin{array}{r}-0.323 \\
(0.197)\end{array}$ & & $\begin{array}{c}-0.352^{*} \\
(0.198)\end{array}$ \\
\hline Constant & $\begin{array}{r}2.708^{* *} \\
(0.154)\end{array}$ & $\begin{array}{c}2.952^{* *} \\
(0.499)\end{array}$ & $\begin{array}{c}1.831^{* *} \\
(0.090)\end{array}$ & $\begin{array}{r}2.203^{* *} \\
(0.503)\end{array}$ & $\begin{array}{r}3.304^{* *} \\
(0.163)\end{array}$ & $\begin{array}{c}1.213^{*} \\
(0.532)\end{array}$ & $\begin{array}{r}3.531^{* *} \\
(0.122)\end{array}$ & $\begin{array}{c}1.414^{*} \\
(0.551)\end{array}$ \\
\hline Observations & 1056 & 805 & 1056 & 805 & 1023 & 785 & 1023 & 785 \\
\hline $\mathrm{R}^{2}$ & 0.058 & 0.092 & 0.063 & 0.093 & 0.012 & 0.053 & 0.013 & 0.052 \\
\hline
\end{tabular}

Robust standard errors in parentheses; ${ }^{\dagger} p<0.05$ (one-tailed), ${ }^{*} p<0.05,{ }^{* *} p<0.01$ (two-tailed).

then asked all the respondents about their attitudes towards Russia. As explained in the previous section, to avoid any deception for the security of the survey respondents and the enumerators, I provided a brief about the Russian bombing of Turkmen towns and cities in Syria, instead of simply changing the country name, and hold all the policy details constant.

Beginning with the Turks' reaction to the treatment, Model 8 shows that the Turks who were informed about the Russian bombing of Turkmen cities express a significantly ( $p<0.05$ one-tailed test) more negative attitude towards Russia than Turks who had not been given this information. In that sense, whereas an average score given to Russia by Turks who were not exposed to the ethnic treatment is 3.66 , it is 3.03 for Turks who were exposed to the ethnic treatment, as reported in Figure 4. Thus, I confirm in-group favoritism among Turks extended beyond the borders ( $\mathrm{H} 1 \mathrm{a})$.

Turks express a more negative attitude towards Russia when informed about Russian policies compared to when they were not informed about these. However, Kurds express a more positive attitude to policies targeting their out-group's brethren in Syria. Accordingly, Model 6 shows that Kurds who were informed about the Russian bombing of Turkmen cities express a significantly less negative attitude towards Russia compared to Kurds who did not receive this information. Whereas an average score given to Russia by Kurds who were not 


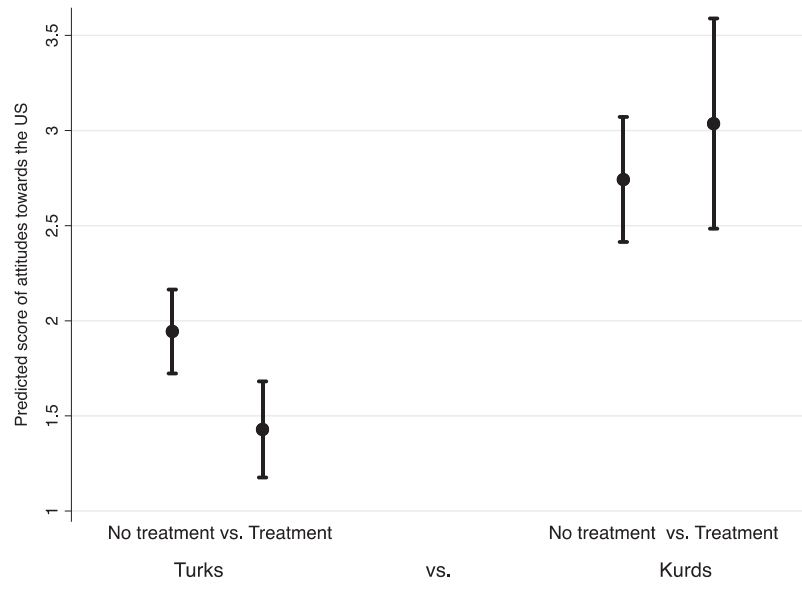

Figure 3. Results of the first experiment

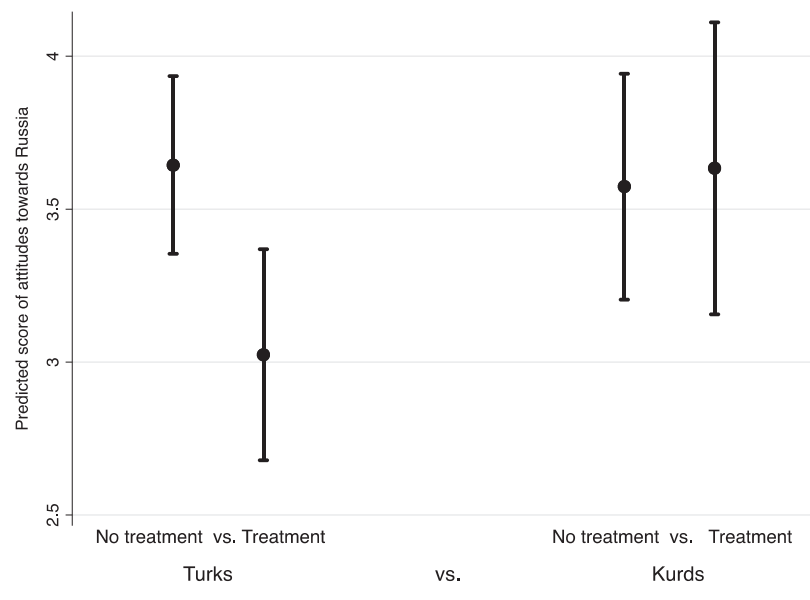

Figure 4. Results of the second experiment

exposed to the ethnic treatment is 3.56 , it is 3.62 for Kurds who were exposed to the treatment. However, there is no statistically significant support for outgroup negativity of Kurds towards Turks in Syria (H2b).

Given that my theoretical expectations find empirical support in regard to Turks, but not to Kurds, I believe the findings deserve closer attention. There may be three plausible reasons for this finding: (1) idiosyncratic factors in the survey design, (2) social desirability bias, and relatedly, (3) a difference in the attitude of the majority vs. the attitude of the minority. Beginning with the first plausible reason, post-estimation analyses reveal that Kurds already show a significantly stronger positive attitude towards the USA than do Turks (see Online appendix D). Mean sympathy score for the USA is 3.30 out of 10 among Kurds, but 2.17 among Turks. This result may hint at the presence of an already existing anchor for Kurds' attitudes towards the USA, which implies that the treatment did not succeed in generating a positive boost in Kurds' sympathy for the USA

Secondly, as an ethnic minority group in a salient identity-based conflict environment, Kurds might have opted for not revealing their true attitudes. As a matter of fact, the Turkish state labelled YPG as a terrorist organization, so showing relatively more positive attitudes toward a country that has positively associated with a terrorist organization might be difficult for Kurds. Therefore, as a more valid test, I rerun the analysis only in Diyarbakir, a Kurdish stronghold where Kurds constitute the overwhelming majority. Being in the majority and answering the survey in a city where most share the same identity may indeed alleviate a possible social desirability bias and set the ground for more accurate responses. In Table II, I report the Kurds' attitudes towards the USA and Russia conditional on their policies in Syria within the Diyarbakir subsample. The results actually confirm Hypothesis 1b: Kurds who received the YPG-treatment showing positive relations between the USA and YPG in Syria, express more positive attitudes toward the USA than Kurds who did not. Regarding the second experiment, on the other hand, my decision to avoid deception may have led to the insignificant change in the Kurds' attitudes towards Russia in the presence of treatment. Unlike the first experiment, the policy details - the Russian bombing of Turkmens - in the treatment are negative. In that sense, it is an even more conservative test, because I expect individuals to express a sense of agreement with the Turkmen casualties, which would be necessary for the manipulation to work.

In addition to the main analysis, the results reveal some other interesting findings. First, we see that people living in Turkey, regardless of their ethnic identity, are more sympathetic to Russia than to the USA. This is not surprising given the ongoing high level of anti-Americanism in Turkey after the Iraq War in 2003. In regard to the control variables, I found that the older the people, the stronger the anti-American attitude they express. Compared to women, men express greater sympathy towards both the USA and Russia. A higher educational level does not have a significant impact on anti-Americanism, though it indicates a pro-Russian attitude. An interesting finding is that with increasing income, anti-Americanism increases whereas anti-Russian attitudes decline. The wealthier people are, therefore, the friendlier they are towards Russia, which could be a result of the increasing trade volume between Turkey and Russia. Lastly, the results show that increasing religiosity among people in Turkey results in stronger anti-American attitudes. However, this trend does not have a significant effect on 
Table II. Focusing on Kurds' attitudes living in Diyarbakir

\begin{tabular}{|c|c|c|c|c|}
\hline DV: Attitudes towards & $\begin{array}{l}\text { (1) } \\
U S\end{array}$ & $\begin{array}{l}\text { (2) } \\
U S\end{array}$ & $\begin{array}{c}\text { (3) } \\
\text { Russia }\end{array}$ & $\begin{array}{c}\text { (4) } \\
\text { Russia }\end{array}$ \\
\hline Kurd (YPG Treatment=1) & $\begin{array}{l}2.562^{*} \\
(1.043)\end{array}$ & $\begin{array}{l}2.819^{*} \\
(1.096)\end{array}$ & & \\
\hline Kurd (Turkmen Treatment $=1)$ & & & $\begin{array}{r}-0.470 \\
\quad(1.354)\end{array}$ & $\begin{array}{l}0.213 \\
(1.328)\end{array}$ \\
\hline YPG Treatment & $\begin{array}{r}-2.125^{*} \\
(0.963)\end{array}$ & $\begin{array}{c}-2.258^{*} \\
(1.021)\end{array}$ & & \\
\hline Turkmen Treatment & & & $\begin{array}{l}0.272 \\
(1.301)\end{array}$ & $\begin{array}{r}-0.027 \\
(1.257)\end{array}$ \\
\hline Kurd & $\begin{array}{c}-0.390 \\
\quad(0.636)\end{array}$ & $\begin{array}{l}-0.267 \\
\quad(0.728)\end{array}$ & $\begin{array}{r}-0.310 \\
(0.617)\end{array}$ & $\begin{array}{r}-0.631 \\
(0.697)\end{array}$ \\
\hline Age & & $\begin{array}{r}-0.058^{* *} \\
(0.018)\end{array}$ & & $\begin{array}{l}-0.011 \\
\quad(0.018)\end{array}$ \\
\hline Male & & $\begin{array}{c}0.958^{*} \\
(0.397)\end{array}$ & & $\begin{array}{l}0.487 \\
(0.381)\end{array}$ \\
\hline Education & & $\begin{array}{l}-0.029 \\
(0.150)\end{array}$ & & $\begin{array}{l}0.020 \\
(0.139)\end{array}$ \\
\hline Income & & $\begin{array}{c}-0.263^{\dagger} \\
(0.134)\end{array}$ & & $\begin{array}{r}-0.253^{\dagger} \\
(0.140)\end{array}$ \\
\hline Urban & & $\begin{array}{l}0.123 \\
(0.468)\end{array}$ & & $\begin{array}{l}-0.429 \\
\quad(0.442)\end{array}$ \\
\hline Religiosity & & $\begin{array}{l}0.139 \\
(0.202)\end{array}$ & & $\begin{array}{r}-0.175 \\
(0.213)\end{array}$ \\
\hline Incumbent Party Support & & $\begin{array}{l}0.234 \\
(0.523)\end{array}$ & & $\begin{array}{l}0.077 \\
(0.530)\end{array}$ \\
\hline Constant & $\begin{array}{r}3.500^{* *} \\
(0.599)\end{array}$ & $\begin{array}{r}5.551^{* *} \\
(1.225)\end{array}$ & $\begin{array}{c}3.478^{* *} \\
(0.581)\end{array}$ & $\begin{array}{r}4.742^{* *} \\
(1.249)\end{array}$ \\
\hline Observations & 266 & 219 & 263 & 220 \\
\hline $\mathrm{R}^{2}$ & 0.019 & 0.112 & 0.005 & 0.043 \\
\hline
\end{tabular}

Robust s.e. in parentheses; ${ }^{\dagger} p<0.05$ (one-tailed), ${ }^{*} p<0.05,{ }^{* *} p<0.01$ (two-tailed).

attitudes towards Russia; even though the majority of Russians are Christian Orthodox.

\section{Robustness checks}

I performed additional analyses to determine whether my results are robust in relation to confounding factors. First, I reran the analysis after removing the respondents who had received sectarian treatment from the data. In so doing, I change the reference point in comparing the results of the ethnic treatment with those for the other conditions. Accordingly, based on the main analysis, I report the effect of ethnic treatment vs. other groups, that is, the control group and the sectarian treatment group, whereas the robustness check compares only the effect of ethnic treatment vs. the control. This approach does not generate any selection bias because all the respondents were randomly assigned to one of the treatment groups or to one of the control groups. The results are thus robust to changes in the reference point (see Online appendix E). In both experiments, compared to the Turks in the control group, the Turks in both the treatment groups express a significantly more negative attitude towards both the USA and Russia. However, the effect is not significant in regard to the heterogeneous treatment effects for Kurds.

Second, I controlled the effect of the first experiment on the second one to check if the results are robust to any possible contamination. As mentioned in the research design section, sensitivity of the topic forced me to avoid a factorial design, in which I could have just changed the policy sender and the recipient names in the vignettes, and instead to include two separate experimental items. This is because I wanted to avoid any deception regarding the US and Russian policies in Syria. Since the US experiment comes first in the questionnaire, there could only be contamination, if any, in the second - Russia experiment. Therefore, I reran the main findings of 
the Russia experiment including a variable indicating whether the respondent received the control, ethnic, or sectarian treatment. As reported in Online appendix $G$, all of the findings are statistically and substantively robust to the control variable, showing the first experiment does not contaminate the findings of the second one.

Third, I controlled for the location effect. The survey was conducted in three cities: Istanbul, Diyarbakir, and Gaziantep. Whereas Istanbul is a highly developed and predominantly Turkish city located far away from the conflict, Diyarbakir, with its Kurdish-majority population, has been the epicenter of the Kurdish secessionist movement. Additionally, Gaziantep is an industrial city that has large Turkish and Kurdish populations. That said, I tested the robustness of my findings in terms of city selection in order to determine the extent to which the city influences individuals' attitudes towards the foreign actors. As reported in Online appendix $\mathrm{H}$, the results hold in general: whereas citizens living in Istanbul express a significantly stronger anti-American attitudes, those living in Diyarbakir do less. In terms of attitudes towards Russia, both Diyarbakir and Istanbul residents show a significantly more pro-Russian attitude.

Lastly, given that ethnocentrism is a key factor in predicting the extent to which individuals' attitudes align with group interests, I empirically tested for the effect of ethnocentrism of Turks and Kurds within and across the treatments they receive. To this end, first, I calculated the ethnocentrism score for each survey respondent by utilizing questions on attitudes towards their in and outgroups (see Online appendix I), and then analyzed whether the level of ethnocentrism influence their attitudes conditional on getting treatment or none. As reported in Appendix I, high ethnocentrism amplifies the effect in general; especially ethnocentric Kurds express a stronger pro-American and a pro-Russian attitude, depending on the treatment they received, compared to those with low ethnocentrism.

\section{Conclusion}

Securing the support of foreign publics is of great importance for states, as public opinion abroad is playing an increasingly significant role in international politics. So far, the literature has focused on the 'action-reaction' chain in analyzing the effects of policy choices on public opinion. Based on this approach, previous studies probe how citizens of a target country react to the policies of a sender state. However, citizens' affiliations and attachments are not limited to the national borders of their countries. Instead, they share many points with other people living abroad. Hence, once the boundary between the concepts of 'home' and 'abroad' is blurred as a result of transnational identity ties, a policy targeting abroad by a third party can have attitudinal and behavioral consequences at home, as well. Accordingly, I embrace a holistic approach in analyzing the impact of foreign policies, for example involvement in a conflict, and investigating their externalities on public opinion in the non-target states.

Based on a survey experiment, I investigate how transnational ethnic ties condition people's attitudes in assessing the USA and Russia as a result of policies relating to the SCW. Even though my sample is not nationally representative, I explore the attitudes of Turks and Kurds in Turkey towards the USA and Russia conditional on their policies in regard to the SCW. The results confirm my theoretical expectations, with Turks who were exposed to information about US support for the Kurdish insurgent group YPG being significantly more likely to express a negative attitude towards the USA compared to the Turks who were not exposed to this information. Similarly, Turks show the same reaction in regard to Russian policies against Turkmens in Syria. In turn, when exposed to the same information about their policies regarding the YPG and Turkmens, respectively, Kurds show a more positive attitude towards the USA and Russia. However, it is necessary to exercise great caution in coming to a conclusion pertaining to the robustness of the results, as the mechanism needs further analysis to determine the extent of the heterogeneous effects given other confounding factors, that is, religious tendencies and sectarian preferences.

The findings of this research demonstrate the impact of domestic cleavages and transnational identity ties on individuals' attitude formation in regard to foreign actors. In this sense, this research is distinct from previous work in this area in accounting for the domestic politics of the target country in predicting public opinion abroad, and hence, in analyzing the externalities of foreign policy choices. Accordingly, it is the spillover effects of those externalities through transnational identities that drive the attitudes of group members. Hence, regardless of the type of policies, they have power to shape public opinion abroad as long as they have a direct or indirect influence on the status quo of domestic power balance at a third-party country. Although the empirical analysis focuses on the respective attitudes of Turks and Kurds towards the USA and Russia, the theoretical foundation makes a greater contribution by extending the 
implications and applications of my findings to other countries, as well. I suggest that the literature on comparative foreign policy and the literature on conflict processes can build on this research and perform a micro-level analysis to predict individuals' reactions to both state actors and violent non-state actors.

Last but not least, this research provides policymakers with crucial lessons in relation to any quest to win hearts and minds abroad. As the findings indicate, it is not only what a state is or does, but also what the target state is and does that conditions people's attitudes towards foreign actors. This result, therefore, challenges the very ideas of soft power and public diplomacy as a way to advance national interests among the public abroad. This is because, as the current study shows, any policy targeting a specific group or country comes with its externalities, which may not serve the policymakers' objectives. Yet, this is still a small step in investigating the impact of foreign policy choices on public opinion abroad, as further research is needed to address the gap in this area of study especially focusing on the moderating effect of contextual factors. In this regard, the attitudinal responses to dynamic and shifting alliances are definitely worth further investigation to see whether a change in the direction of policies, as in the case of US withdrawal from Syria or ups and downs in Russia-Turkey relations.

\section{Replication data}

The Online appendices, data supplements, dataset, codebook, and do-files for the empirical analysis in this article can be found at http://www.prio.org/jpr/datasets and www.efetokdemir.com.

\section{Acknowledgements}

I thank Seden Akcinaroglu, Burcu Bayram, Dave Clark, Aysenur Dal, Alper Ecevit, Benjamin Fordham, Ekrem Karakoc, Joshua Kertzer, Ege Ozen, Katerina Vrablikova, Birol Yesilada, and the editors and anonymous reviewers of the Journal of Peace Research for their contributions and helpful comments. All errors are my own. Efe Tokdemir acknowledges the financial support of Young Scientist Award (BAGEP) of The Science Academy, Turkey.

\section{ORCID iD}

Efe Tokdemir (1) https://orcid.org/0000-0002-9579-1292

\section{References}

Bayram, Burcu (2016) Aiding strangers: Generalized trust and the moral basis of public support for foreign development aid. Foreign Policy Analysis 13(1): 133-153.

Becker, Per (2009) Vulnerability and nationalism: The support for the war against Iraq in five established states. Nations and Nationalism 15(2): 340-360.

Blaydes, Lisa \& Drew A Linzer (2012) Elite competition, religiosity, and anti-Americanism in the Islamic world. American Political Science Review 106(2): 225-243.

Brewer, Marilyn B (2011) Identity and conflict. In: Daniel Bar-Tal (ed.) Intergroup Conflicts and Their Resolution: A Social Psychological Perspective. New York: Psychology, 125-144.

Buhaug, Halvard \& Kristian Skrede Gleditsch (2008) Contagion or confusion? Why conflicts cluster in space. International Studies Quarterly 52(2): 215-233.

Bush, Sarah \& Amaney Jamal (2014) Anti-Americanism, authoritarian politics, and attitudes about women's representation: Evidence from a survey experiment in Jordan. International Studies Quarterly 59(1): 34-45.

Cederman, Lars Erik; Kristin Skrede Gleditsch, Idean Salehyan \& Julian Wucherpfennig (2013) Transborder ethnic kin and civil war. International Organization 67(2): 389-410.

Chiozza, Giacomo (2010) Anti-Americanism and the American World Order. Baltimore, MD: Johns Hopkins University Press.

Cizre, Ümit (2001) Turkey's Kurdish problem: Borders, identity and hegemony. In: Brendan O'Leary, Ian Lustick \& Thomas Callaghy (eds) Right-Sizing the State: The Politics of Moving Borders. Oxford: Oxford University Press, 222-252.

Corstange, Daniel \& Nikolay Marinov (2012) Taking sides in other people's elections: The polarizing effect of foreign intervention. American Journal of Political Science 56(3): 655-670.

Coser, Lewis (1956) The Functions of Social Conflict. New York: Routledge.

Fiske, Susan; Amy Cuddy \& Peter Glick (2007) Universal dimensions of social cognition: Warmth and competence. Trends in Cognitive Sciences 11(2): 77-83.

Gaines, Brian; James Kuklinski, Paul Quirk, Buddy Peyton \& Jay Verkulien (2007) Same facts, different interpretations: Partisan motivation and opinion on Iraq. Journal of Politics 69(4): 957-974.

Gelpi, Christopher (2010) Performing on cue? The formation of public opinion toward war. Journal of Conflict Resolution 54(1): 88-116.

Gelpi, Christopher; Peter Feaver \& Jason Reifler (2006) Success matters: Casualty sensitivity and the war in Iraq. International Security 30(3): 7-46.

Greenwald, Anthony; Mahzarin Banaji, Laurie Rudman, Shelly Farnham, Brian Nosek \& Deborah Mellot (2002) A unified theory of implicit attitudes, stereotypes, self-esteem and self-concept. Psychological Review 100(1): 3-25. 
Heider, Fritz (1958) The Psychology of Interpersonal Relations. New York: Wiley.

Herrmann, Richard (2017) How attachments to the nation shape beliefs about the world: A theory of motivated reasoning. International Organizations 71(Supplement): S61-S84.

Herrmann, Richard; Philip Tetlock \& Penny Visser (1999) Mass public decision on go to war: A cognitive-interactionist framework. American Political Science Review 93(3): 553-573.

Hewstone, Miles; Mark Rubin \& Hazer Willis (2002) Intergroup bias. Annual Review of Psychology 53: 575-604.

Holsti, Ole (2004) Public Opinion and American Foreign Policy. Ann Arbor, MI: University of Michigan Press.

Horowitz, Donald (1985) Ethnic Groups in Conflict. London: University of California Press.

Huddy, Leonie (2013) From group identity to political cohesion and commitment. In: Leonie Huddy, David O Sears \& Jack Levy (eds) The Oxford Handbook of Political Psychology, 2nd edition. Oxford: Oxford University Press, 737-773.

Hummon, Norman \& Patrick Doreian (2003) Some dynamics of social balance processes: Bringing Heider back into balance theory. Social Network 25(1): 17-49.

Hurwitz, Jon \& Mark Peffley (1987) How are foreign policy attitudes structured? A hierarchical model. American Political Science Review 81(4): 1099-1120.

Jentleson, Bruce (1992) The pretty prudent public: Post post-Vietnam American opinion on the use of military force. International Studies Quarterly 36(1): 49-74.

Kahan, Dan M (2016) The politically motivated reasoning paradigm: What politically motivated reasoning is and how to measure it. In: Robert Scott, Stephen Kosslyn \& Marlis Buchmann (eds) Emerging Trends in the Social and Behavioral Sciences: An Interdisciplinary, Searchable, and Linkable Resource. Wiley Online Library.

Kam, Cindy \& Donald Kinder (2007) Terror and ethnocentrism: Foundations of American support for the war on terrorism. Journal of Politics 69(2): 320-338.

Kertzer, Joshua; Kathleen Powers, Brian Rathbun \& Ravi Iyer (2014) Moral support: How moral values shape foreign policy attitudes. Journal of Politics 76(3): 825-840.

Kirişçi, Kemal \& Gareth Winrow (1997) The Kurdish Question and Turkey: An Example of a Trans-State Ethnic Conflict. London: Frank Cass.

Kunda, Ziva (1990) The case for motivated reasoning. Psychological Bulletin 108(3): 480-498.

Lake, David A \& Donald Rothchild (1998) The International Spread of Ethnic Conflict: Fear, Diffusion, and Escalation. Princeton, NJ: Princeton University Press.

Lau, Richard \& David Redlawsk (2001) Advantages and disadvantages of cognitive heuristics in political decision making. American Journal of Political Science 45(4): 951-971.

LeVine, Robert \& David Campbell (1972) Ethnocentrism: Theories of Conflict, Ethnic Attitudes, and Group Behavior. New York: John Wiley \& Sons.
Lodge, Milton \& Charles Taber (2000) Three steps toward a theory of motivated political reasoning. In: A Arthur Lupia \& Matthew McCubbins (eds) Elements of Reason: Cognition, Choice, and the Bounds of Rationality. New York: Cambridge University Press, 183-213.

Lynch, Mark (2007) Anti-Americanism in the Arab world. In: Peter Katzenstein \& Robert O Keohane (eds) Anti-Americanisms in World Politics. Ithaca, NY: Cornell University Press, 196-226.

Miller, Abraham; Louis Bolce \& Mark Halligan (1977) The J-curve theory and the black urban riots: An empirical test of progressive relative deprivation theory. American Political Science Review 71(3): 964-982.

Nye, Joseph S (2004) Soft Power: The Means to Success in World Politics. New York: PublicAffairs.

Oakes, Penelope (2002) Psychological groups and political psychology: A response to Huddy's 'Critical examination of social identity theory'. Political Psychology 23(4): 809-824.

Popkin, Samuel (1991) The Reasoning Voter. Chicago, IL: University of Chicago Press.

Pratto, Felicia; James Sidanius, Lisa M Stallworth \& Bertram Malle (1994) Social dominance orientation: A personality variable predicting social and political attitudes. Journal of Personality and Social Psychology 67(4): 741-763.

Pratto, Felicia; James Sidanius, Fouad B Zeineddine, Nour Kteily \& Shana Levin (2014) When domestic politics and international relations intermesh: Subordinated publics' factional support within layered power structures. Foreign Policy Analysis 10(2): 127-148.

Radziszewski, Elisabeth (2013) Interpersonal discussions and attitude formation on foreign policy: The case of Polish involvement in the Iraq war. Foreign Policy Analysis 9(1): 103-123.

Ross, Lee (1995) Reactive devaluation in negotiation and conflict resolution. In: Kenneth Arrow, Robert Mnookin, Lee Ross, Amos Tversky \& Robert B Wilson (eds) Barriers to Conflict Resolution. New York: WW Norton, 27-42.

Ross, Lee \& Constance A Stillinger (1988) Psychological Barriers to Conflict Resolution. Stanford, CA: Stanford University.

Ross, Lee \& Constance A Stillinger (1991) Barriers to conflict resolution. Negotiation Journal 7(4): 389-404.

Ross, Lee \& Andrew Ward (1995) Naive realism in everyday life: Implications for social conflict and misunderstanding. In: Edward Reed, Elliot Turiel \& Terrance Brown (eds) Values and Knowledge. Hillsdale, NJ: Erlbaum.

Saideman, Stephen M (2001) The Ties that Divide. New York: Columbia University Press.

Sarigil, Zeki \& Ekrem Karakoc (2017) Inter-ethnic (in) tolerance between Turks and Kurds: Implications for Turkish democratization. South European Society and Politics 22(2): 197-216.

Sherif, Muzafer (1967) Social Interaction: Process and Products. London \& New York: Routledge. 
Spears, Russell (2011) Group identities: The social identity perspective. In: Seth Schwartz, Koen Luyckx \& Vivian Vignoles (eds) Handbook of Identity Theory and Research. New York: Springer, 201-224.

Tajfel, Henri (1981) Human Groups and Social Categories. Cambridge: Cambridge University Press.

Tajfel, Henri (1982) Social Identity Theory and Intergroup Relation. Cambridge: Cambridge University Press

Tajfel, Henri \& John Turner (1979) Integrative theory of intergroup conflict. In: William Austin \& Stephen Wrochel (eds) The Social Psychology of Intergroup Relations. Totnes: Brooks/Cole, 33-47.

Telhami, Shibley \& Michael Barnett (2002) Identity and Foreign Policy in the Middle East. Ithaca, NY: Cornell University Press.

Tokdemir, Efe; Seden Akcinaroglu, H Ege Ozen \& Ekrem Karakoc (2020) 'Wars of others': National cleavages and attitudes toward external conflicts. International Interactions. https://doi.org/10.1080/03050629.2020.1792898.
Turner, John; Michael Hogg, Penelope Oakes, Stephen Reciher \& Margaret Wetherell (1987) Rediscovering the Social Group: A Self-Categorization Theory. Oxford: Basil Blackwell.

Tversky, Amos \& Daniel Kahneman (1974) Judgment under uncertainty: Heuristics and biases. Science 185(4157): 1124-1131.

Weidmann, Nils B (2015) Communication networks and the transnational spread of ethnic conflict. Journal of Peace Research 52(3): 285-296.

EFE TOKDEMIR, b. 1988, PhD in Political Science (Binghamton University, 2017); Assistant Professor of International Relations at Bilkent University, Turkey; research interests: foreign policy and public opinion, international relations and domestic politics, conflict processes, terrorism; articles have appeared in Journal of Peace Research, Conflict Management and Peace Science, International Interactions, Electoral Studies, and International Political Science Review. 